Para citar este artículo: Da Silva, D. W. S., \& Baldissera, R. (2021). Organizational Communication and Invisibility Strategies and Reducing/Targeting Social Media Visibility. Anuario Electrónico de Estudios en Comunicación Social "Disertaciones", 14(1), 1-17. https://doi.org/10.12804/revistas.urosario.edu.co/ disertaciones/a.9058

\title{
ORGANIZATIONAL COMMUNICATION AND INVISIBILITY STRATEGIES AND REDUCING/ TARGETING SOCIAL MEDIA VISIBILITY
}

La comunicación organizacional y las estrategias de invisibilidad y reducción/ focalización de la visibilidad en las redes sociales

A comunicação organizacional e as estratégias de invisibilidade e de redução / direcionamento de visibilidade nas redes sociais

Diego Wander Santos da Silva, Universidade Federal do Rio Grande do Sul (UFRGS) e Pontifícia Universidade Católica do Rio Grande do Sul (PUCRS)

diego.wander@pucrs.br

Rudimar Baldissera, Universidade Federal do Rio Grande do Sul (UFRGS)

rudimar.baldissera@ufrgs.br

Recibido: 2 de mayo de 2020

Aceptado: 29 de junio de 2020

Fecha de prepublicación: 1 de diciembre de 2020 


\section{DISERTACIONES}

\section{AVANCES}

\section{ABSTRACT}

This article begins with discussions about organizational communication, especially in the context of social media. Research in this field tends to emphasize "visibility" as the only desire of organizations in online environments. However, "strategies of invisibility" are also paths adopted by organizations in situations of risk or in the face of the apparent advance of guidelines that contradict the way they expect to be recognized. Our aim is to understand the strategies of organizations in situations requiring invisibility and reducing/targeting visibility on social media. The discussions refer to symbolic interactionism, which is the epistemic foundation of this research. On an empirical level, we conducted in-depth interviews with 17 professionals working in digital communication agencies. The results form a map of strategies for invisibility and reducing/targeting visibility, which indicates the professionalization and several consequences of these processes and resources. Our understanding is that such strategies need discussion in the light of notions of public interest, conformity, and ethics, as the prospect of concealment may represent the non-visibility of issues relevant to society that are losing emphasis, given the refinement of these processes and resources.

Keywords: Organizational communication; strategies; invisibility; social media; digital communication agencies.

\section{RESUMEN}

El propósito de este artículo parte de las discusiones sobre comunicación organizacional, especialmente en el contexto de las redes sociales. Nos dimos cuenta de que la investigación en esta área tiende a enfatizar la "visibilidad" como el único deseo de las organizaciones en ambientes digitales. Sin embargo, las "estrategias de invisibilidad" también se presentan como caminos tomados por organizaciones en riesgo o ante el aparente crecimiento de pautas que pueden contradecir cómo esperan ser conocidas. Nuestro objetivo es comprender cuáles son las estrategias de las organizaciones en situaciones donde el deseo de invisibilidad y la reducción/focalización de la visibilidad en los sitios de redes sociales. Las discusiones se refieren al interaccionismo simbólico, fundamento epistémico de esta investigación. A nivel empírico, realizamos entrevistas en profundidad a 17 profesionales que laboran en agencias de comunicación digital. El resultado de este estudio es un mapa de estrategias de invisibilidad y reducción/focalización de visibilidad que indica profesionalización y varios problemas en relación a estos procesos y recursos. Entendemos que tales estrategias deben ser discutidas a la luz de las nociones de interés público, conformidad y ética, ya que la perspectiva del encubrimiento puede representar la no visibilidad de temas relevantes para la sociedad que están perdiendo espacio debido al refinamiento de estos procesos y recursos.

Palabras clave: comunicación organizacional; estrategias; invisibilidad; medios de comunicación social; agencias de comunicación digital. 


\section{DISERTACIONES}

\section{AVANCES}

Los desafios del periodismo narrativo

ISSN: 1856-9536

Doi: https://doi.org/10.12804/revistas.urosario.edu.co/disertaciones/a.9058

Volumen 14, Número 1 / Enero-junio 2021

Versión PDF para imprimir desde

http://revistas.urosario.edu.co/index.php/disertaciones

\section{RESUMO}

A proposição deste artigo parte das discussões sobre comunicação organizacional, especialmente no contexto das mídias sociais. Percebemos que pesquisas nessa área tendem a enfatizar a "visibilidade" como o único desejo das organizações em ambientes online. No entanto, "estratégias de invisibilidade" também se apresentam como caminhos adotados por organizações em situação de risco ou diante do aparente avanço de diretrizes que podem contradizer a forma como esperam ser conhecidas. Nosso objetivo é compreender quais são as estratégias das organizações em situações em que o desejo de invisibilidade e de redução/direcionamento da visibilidade em sites de mídia social. As discussões referem-se ao interacionismo simbólico, fundamento epistêmico desta pesquisa. No nível empírico, realizamos entrevistas em profundidade com 17 profissionais que atuam em agências de comunicação digital. O resultado deste estudo é um mapa de estratégias de invisibilidade e redução/direcionamento de visibilidade que indica a profissionalização e diversos problemas em relação a esses processos e recursos. Nosso entendimento é que tais estratégias precisam ser discutidas à luz das noções de interesse público, conformismo e ética, uma vez que a perspectiva de encobrimento pode representar a não visibilidade de questões relevantes para a sociedade que estão perdendo espaço pelo refinamento desses processos e recursos.

Palavras-chave: comunicação organizacional; estratégias; invisibilidade; mídia social; agências de comunicação digital.

\section{Introduction}

Within scenarios guided by the extraordinary and also apparent horizon of visibility, the ways and techniques used with this purpose appear to be one of the central challenges of those who have organizations as the main study object or job in the academia and in the market. However, studies that approach this theme tend to overlook the fact that being on center stage and in the spotlight can be negative, especially when the correlated subjects and their focuses are adverse or simply not interesting. In these cases, conveniently, the companies tend to present a range of strategies that aim to step off the stage, in order to reduce visibility. In more extreme cases, they can even deny any involvement in a certain situation or in holding accountability to society.

When we talk about invisibility and reduction/targeting of visibility, we refer to possible organizational strategies that are put in action as soon as risks are identified or subjects are brought to attention (in society or in the media). This act can follow the way in which companies wish to be noticed. Because these risks or subjects can 


\section{DISERTACIONES}

AVANCES

clash with the projected senses put in action by the organization within the management practices in the scope of the communicated organization (Baldissera, 2009), ${ }^{1}$ it is possible and even legit that organizations aim to minimize these impacts.

The invisibility and the reduction/targeting of visibility in social media constitute the object of study in this paper. Possibly, there is a set of possibilities, still unknown from the theoretical point of view, that are able to express the solutions chosen and adopted in these situations, which are related to the technological characteristics and sociotechnical resources available at these websites.

The research question that guides the present study is that the disguise created by the invisibility strategies can oppose to public interest notions, transparency, and society's right to information. This is especially harmful when the adopted strategies (which represent the organization's interests) undermine or hide facts of public interest or even present partial versions of the facts as if they were true. The article presents a correlation with the discussions towards the private and public dimensions sometimes intentionally ignored by the organization during critical times when there are risks of financial loss or big negative impacts in terms of concept images. ${ }^{2}$

The main objective, then, is to understand what the strategies used by the organizations are during situations in which they desire invisibility and reduction/targeting of the visibility in social media. The symbolic interactionism is the underlying epistemic perspective in which this research builds itself. This choice shows the comprehension and point of view that the communication phenomenon has accomplished within the symbolic interaction process. ${ }^{3}$ Besides that, it is assumed that the environment of social media can be perceived as a spaces' simulation in which the organizations and agencies look for good performances. ${ }^{4}$

Thus, paying attention to the communication that materializes in social media, the sociotechnical perspective ${ }^{5}$ is important (Lasta, 2017). The constructed meaning is not dissociated from the technologies, contexts, intentions, and strategies updated by the individuals and organizations that participate in the interactions. In addition, based on Goffman's (2009) theories, we assume that the environments of social media are spaces for presentation (to be seen) and representation/performance for individuals and organizations, which can be situations of sincere performance or of cynical acting. Considering the imperative of visibility and strategy for organizations in the context

1 According to Baldissera (2009), the expression refers to the "formal and even disciplinatory, of authorized speech, towards what the organization selects from its identity and, through communicational processes (strategic or not), there is visibility with the aim of feedback on concept images, legitimacy, symbolic capital (and acknowledgement, sales, profit, votes, etc.)" (p. 118, author's translation).

2 According to Baldissera (2008), concept image can be defined "as [a] symbolic construction, both complex and synthetizing, of adjudicative/characterizing and temporary nature, made by the alterity (reception) through permanent tensions that are dialogic, dialectical, and recursive, inside and between a diversity of strength-elements, such as the information and perceptions about the entity (something/someone), the individual/social repertory, the competences, the culture, the imagery, the paradigm, the psyche, the history, and the structured context" (p. 198, author's translation).

3 In other words, in the coding and decoding of verbal and non-verbal signs among interlocutors.

4 In this sentence, we resort to Goffman's (2009) metaphors. He reflects on the ideas of simulations, masks, stage, and representation, among others.

5 Socio-technics means the articulation between the social and technological systems, particularly in terms of information and communication technologies (Lasta, 2017). 


\section{DISERTACIONES}

AVANCES

Los desafios del periodismo narrativo

ISSN: 1856-9536

Doi: https://doi.org/10.12804/revistas.urosario.edu.co/disertaciones/a.9058

Volumen 14, Número 1 / Enero-junio 2021

Versión PDF para imprimir desde

http://revistas.urosario.edu.co/index.php/disertaciones

of deep symbolic disputes, in tension with the discourse of transparency, ethics and systemic interdependence and cynical representations tend to assume centrality, as we can see from the empirical data presented in this article.

We hope that this research inspires further developments in the discussion of organizational communication, particularly its relation to the strategies of (in)visibility of social media issues. In order to comprehend and problematize the discursive strategies and their management, it is important to bring them into the light of people (the audiences), that daily consume, access, and interact with the signs broadcasted not always with critical and reflexive potential to judge what is visible or not. Advancing in the discussion of these matters may contribute to see these spaces beyond the already purposed senses. This should help us have more clarity about other possible dynamics that might be in exclusive service of the organizations.

\section{The invisibility perspective}

Invisibility is understood as situations in which something or someone is not visible to someone -an audience or even search engines on the internet (or at least is not relevant to these mechanisms)-. In this sense, we can think in several perspectives towards invisibility, of which we highlight being in a non-visibility area, not have sociotechnical importance to be visible, act in order to put the visibility in something else, or "create" cloudy contexts and scenarios so that the hidden fact is kept invisible, among other possibilities. These practices can hide, reduce, or even shift the course of visibility, assuring that a piece of information is not publicized, that it does not become public knowledge, fulfilling certain interests that may conflict or not with dimensions that concern conformity or even legal issues.

Within the context of organizations, there are discussions that seem appropriate and are presented in this discussion: In which levels the desire of not being seen can collide with the understanding of public interest? In which measure these strategies can cover information that should be shared, because of the rights of the audiences to access information? What are the suitable considerations in an ethical stance, concerning transparency and even respect to society? These are questions that were constant in our understanding and created an unsettling behavior that inspired us to reflect on the strategies of invisibility and constraint/targeting of organizations' visibility, mainly in social media.

Regarding management practices, we see concepts such as accountability ${ }^{6}$ gaining power, presenting itself as an initiative for permanent, consistent, and systematic control of ethical standards. It points to transparency in management practices, transactions, and finance as a priority concern and emerging need. It motivates organizations to a variety of reports, usually materialized in robust but not always clear documents, that are made public with the purpose of disseminating and informing organizational movements. At least discursively, it demonstrates the desire to clarify facts.

6 The concept of accountability is related to so-called good governance policies. It involves accountability guided by the internationally required ethical standards, according to Rossetti and Andrade (2014). 


\section{DISERTACIONES}

\section{AVANCES}

Los desafios del periodismo narrativo

ISSN: 1856-9536

Doi: https://doi.org/10.12804/revistas.urosario.edu.co/disertaciones/a.9058

Volumen 14, Número 1 / Enero-junio 2021

Versión PDF para imprimir desde

http://revistas.urosario.edu.co/index.php/disertaciones

However, to what extent is it possible for them to shine on certain subjects to create zones of darkness over others? Are, in fact, invisibility strategies consistent solutions? Or, do they show weaknesses (relevant and contradictory) in organizations? Furthermore, what is the ability of people to read the published data critically? To what extent can it not be configured as manipulative initiatives that seek to establish trust, based on narratives full of business jargon?

The research problem, in our case, is in the subversion of said transparent initiatives, which carry a symbolic load, but can assume the only versions of organizations, that, sometimes, are biased. After all, there is a possibility that messages and contents, before being seen, go through filters that are opportune to the organizations and adequate to moral requisites, normalizations, social codes, and sensitive judgments from the audiences.

Under this light, it is understood that invisibility (especially from/towards critical issues) can be a desire towards organizational communication practices. This dynamic, we assume, is enhanced, in this context, by the decrease of the closed models and strategies of communication and by the intensification of unpredictable and uncertain events inherent to the communicational processes, a phenomenon which involves equally ethical and moral markers.

In this direction, organizations may appeal to printing management techniques, to the "art of designing and executing a certain form of communication or interaction so that the audience reaches conclusions or planned behaviors" (Wood Jr., 2001, p. 153). These strategies are materialized from the use of symbolic arsenal, and the symbols can engender different interpretations since they are correlated to the cultural context and the repertoire of the audiences. The idea of conformity indicates that people tend to shape their behaviors according to the results they want to obtain, which is independent of their values - at least of those that are seen as guiding principles-. Thus, the organizational identity can be ignored, at different levels, increasing the distance between what an organization really is and delivers and what it sustains in the relationship with the public and with society.

Henriques and Silva (2014) have timely contributions to these reflections. They pay attention to the fact that the public, vulnerable by different situations, starts promoting initiatives with the purpose of supervising and monitoring abusive communication practices of organizations, reconfiguring "elements of the multifaceted organization-society relationship" (p. 1). For these authors, audiences increasingly present themselves as questioners and combatants of official discourses and practices (un)communicated. In this scenario, there are initiatives that seek to "amplify the formation of a public court, demand responsibility and pressure the authorities to trigger the legal effects" (Henriques \& Silva, 2014, p. 4). An example of this is the Center for Media and Democracy (см⿰), an American non-profit organization that seeks to denounce abusive communication practices by the private sector. However, the same authors pay attention to the limits of this surveillance, which also occurs with the press, which is often inefficient in terms of monitoring organizations. The authors also highlight some practices that help us to envision invisibility strategies. Among them:

The distortion of information about private interests, the attempt to plant fallacious news, the creation of false events, the act of spreading rumors, the simulation of audiences or of situations that can influence audiences, the creation of fake organizations to disseminate information or to defend certain points of view as a disinterested third party or the action of recruiting scientists so that they, without disclosing their links with the organizations, try to influence the debate about public controversies appearing neutral (Henriques \& Silva, 2014, p. 4). ${ }^{7}$

7 Author's translation. 


\section{DISERTACIONES}

AVANCES

Los desafios del periodismo narrativo

ISSN: $1856-9536$

Doi: https://doi.org/10.12804/revistas.urosario.edu.co/disertaciones/a.9058

Volumen 14, Número 1 / Enero-junio 2021

Versión PDF para imprimir desde

http://revistas.urosario.edu.co/index.php/disertaciones

A problem pointed out, by Henriques and Silva (2014), is the slowness of the legal advances that curb these events. We also highlight the practice of astroturfing, which allows us to think about the strategic and symbolic arsenal that can be shifted in an attempt to produce meanings and influence perceptions. The concept arises in the American political context, in the 1980s, and shows the appeal to groups of people who express apparently genuine opinions, but which result from motivations of another order (Hoggan, 2006). The empowered senses, when put into circulation, tend to impact other subjects in a systematic and chain way; "it is a practice surrounded by several ethical ambiguities, something that works with efforts to deceive people, make them believe in false aspects of a reality and, thus, hide private interests" (Silva, 2013, p. 10). ${ }^{8}$

Henriques and Silva (2014) also highlight the possibilities for the execution of corporate crimes, a term that, according to them, "designates the infringement of legal provisions that vary in each place, covering actions or omissions of companies and corporations that are typified as a crime" (p. 3), ${ }^{9}$ which range from effectively illegal practices to irresponsibility caused by omission and negligence. The (in)visibility, in these cases, can be directly related to the desire to corrupt public opinion, not just to avoid questions about commitment with the law. In this sense, the preservation of the concept image and the reputation of organizations are closely linked to strategies and the desire for restricting visibility.

The internet also constitutes/hosts opportune spaces for practices with these characteristics. Silva (2013) states that the relationship between astroturfing and the internet, as far as is known, dates back to 1994. Over the years, manifestations in forums and chat rooms, especially in electoral periods, have become customary associated with these practices. In fact, Henriques and Silva (2014) assert that "in the last two decades, the main Public Relations agencies in the world have been the target of complaints about the use" $(p .7)^{10}$ of this technique in strategic actions for several organizations. We understand that this fact ensures the professionalization of the processes that we discussed in our study. They signal the extent to which some apparently organic practices can come from paths and solutions that are far from organic, leading to mistaken readings about the relevance of certain subjects.

\section{Methodological procedures}

Given the features of our research object, we chose to carry out in-depth interviews of mixed nature. In this process, in-depth interviews were conducted with seventeen professionals (agency directors or team leaders, responsible for areas such as Customer Service, Planning, Content, and Creation) from fourteen digital communication agencies.

About the criteria in selecting the participants, we recurred to agencies affiliated to the Brazilian Association of Digital Agents (the acronym in Portuguese is Abradi, which stands for Associação Brasileira dos Agentes Digitais), that is the most important Brazilian entity focused on digital communication. Among 176 affiliated agencies, we chose the ones which met the following requirements: a) Offer social media services; b) accessibility to the researcher, and c) availability and interest from the agencies. At the end, there were 21 agencies, from which we

8 Author's translation.

9 Author's translation.

10 Author's tanslation. 


\section{DISERTACIONES}

\section{AVANCES}

Los desafios del periodismo narrativo

ISSN: 1856-9536

Doi: https://doi.org/10.12804/revistas.urosario.edu.co/disertaciones/a.9058

Volumen 14, Número 1 / Enero-junio 2021

Versión PDF para imprimir desde

http://revistas.urosario.edu.co/index.php/disertaciones

selected 14, in order to include organizations of different sizes. The detailed three steps took us to the informants involved in the process of collecting data (Table 1).

Table 1. Interviewees: Training, Size and Agency’s Headquarters

\begin{tabular}{|c|c|c|}
\hline University Graduation Course & Size of Agency & Headquarter ${ }^{11}$ \\
\hline Advertising and Marketing & Medium & São Paulo \\
\hline Journalism, with post-graduation studies in International Politics & Big & Rio Grande do Sul \\
\hline Advertising and Marketing & Small & São Paulo \\
\hline Graphic Design, with post-graduation studies in Marketing & Medium & São Paulo \\
\hline Journalism, with post-graduation studies in Strategic Business Management & Big & Rio Grande do Sul \\
\hline Advertising and Marketing & Medium & Rio de Janeiro \\
\hline Information Systems Technology & Big & Santa Catarina \\
\hline Journalism, with post-graduation studies in Digital Marketing & Small & São Paulo \\
\hline Journalism & Small & Santa Catarina \\
\hline Journalism (interviewee 1) and Radio and Television (interviewee 2) & Small & São Paulo \\
\hline Journalism, with post-graduation studies in Semiotics & Big & São Paulo \\
\hline $\begin{array}{l}\text { Business Administration (interviewee } 1 \text { ) and Advertising and Marketing, with } \\
\text { post-graduation studides in Fashion, Service and Social Medias (interviewee 2) }\end{array}$ & Medium & São Paulo \\
\hline Business Administration & Small & São Paulo \\
\hline Advertising and Marketing (interviewee 1) and Journalism (interviewee 2) & Big & Rio Grande do Sul \\
\hline
\end{tabular}

Source: By the authors.

We see that these steps helped us to establish suitable guidelines for the final setting up of the interviewed professionals. In total, 14 interviews were conducted. In three agencies, the interviews counted with two professionals. The data were analyzed by the content analysis technique from Bardin (2011). We followed the phases proposed by the methodology, organized into three poles: pre-analysis, material exploration, and the treatment of results (inference and interpretation). After the pre-analysis, which involves the preparation of the material (transcription of the collected reports), we started to explore the contents, the most exhaustive phase of the procedure. At that point, we created the encodings and categorizations. We group close and complementary meanings with the purpose of creating categories of analysis (Bardin, 2011), which reveal the different strategies of invisibility and reduction of visibility in social media.

11 We only mention the State of the agencies to preserve their anonymity. 


\section{DISERTACIONES}

AVANCES

\section{Research Results}

We present the categories and subcategories revealed by the theoretical background and complemented/revised from the discoveries that emerged from the data collection. After a series of redesigns, we decided that the systematization represents the group of strategies in which prevails the wish of not show/be visible, as well as the intention of diagnosing the visibility or invisibility and target or constrain the visibility.

In total, there are seven categories (strategies). They are combined regarding their purpose/intentionality. Each one of the strategies contains subcategories that guide the emphasis and the used sociotechnical solutions. The subcategories express a specific core sense (Table 2).

Table 2. Invisibility and Constraint/Targeting of the Visibility

\begin{tabular}{|c|c|c|c|}
\hline $\begin{array}{c}\text { Purposes/ } \\
\text { Intentionality }\end{array}$ & $\begin{array}{l}\text { Categories } \\
\text { (Strategies) }\end{array}$ & $\begin{array}{l}\text { Subcategories } \\
\text { (Emphasis) }\end{array}$ & Core Senses \\
\hline \multirow{2}{*}{$\begin{array}{l}\text { Diagnose the } \\
\text { visibility and } \\
\text { the invisibility }\end{array}$} & \multirow{2}{*}{$\begin{array}{l}\text { Monitoring the } \\
\text { risk situations }\end{array}$} & Risk identification & $\begin{array}{l}\text { Prevention of possible crisis or of the visibility of } \\
\text { "negative" agendas; foresight planning towards possible } \\
\text { necessary interventions. }\end{array}$ \\
\hline & & $\begin{array}{l}\text { Follow up on crisis and its } \\
\text { outcomes }\end{array}$ & $\begin{array}{l}\text { Systematization of sensible mechanisms that catch risk } \\
\text { situations; attention to "crisis agents" and understanding/ } \\
\text { follow-up on the protagonists. }\end{array}$ \\
\hline \multirow{4}{*}{ Target visibility } & \multirow{4}{*}{$\begin{array}{l}\text { Public expression } \\
\text { of an institutional } \\
\text { stance }\end{array}$} & $\begin{array}{l}\text { Official positioning } \\
\text { presentation }\end{array}$ & $\begin{array}{l}\text { Contrast between the versions presented by the } \\
\text { interlocutors in high relevance and incidence cases (or } \\
\text { cases that have the potential of being of high relevance). }\end{array}$ \\
\hline & & $\begin{array}{l}\text { Feedback and reply to } \\
\text { requests }\end{array}$ & $\begin{array}{l}\text { Need to answer all the solicitations from the public; direct } \\
\text { relation between the absence of replies and the growth of } \\
\text { the crisis reach, and "negative" agenda. }\end{array}$ \\
\hline & & $\begin{array}{l}\text { Promptness and } \\
\text { 'transparency'12 in the } \\
\text { request replies }\end{array}$ & $\begin{array}{l}\text { Relevance in the monitoring and the qualification of the } \\
\text { teams aiming on more prompt and transparent replies; } \\
\text { direct relation between the slow replies and growth of the } \\
\text { crisis reach, and "negative" agenda. }\end{array}$ \\
\hline & & $\begin{array}{l}\text { Capability to solve problems } \\
\text { in face of the requests }\end{array}$ & $\begin{array}{l}\text { Direct relation between the capability to solve problems } \\
\text { and the decline of crisis impact and "negative" agenda. }\end{array}$ \\
\hline
\end{tabular}

12 We use the word transparency in simple quotation marks to highlight that this idea is circumstantial, in a way that it reveals what is said - what is - but this saying is always limited, because it never means a complete transparency, which is also a characteristic of a strategic speech. Even though this word is not the most suitable, we use it aware of this remark, mainly because our interviewees used the term. 


\begin{tabular}{|c|c|c|c|}
\hline $\begin{array}{l}\text { Purposes/ } \\
\text { Intentionality }\end{array}$ & $\begin{array}{l}\text { Categories } \\
\text { (Strategies) }\end{array}$ & $\begin{array}{l}\text { Subcategories } \\
\text { (Emphasis) }\end{array}$ & Core Senses \\
\hline \multirow{8}{*}{ Target visibility } & \multirow{8}{*}{$\begin{array}{l}\text { Shuffle of facts } \\
\text { and emphasis } \\
\text { of making } \\
\text { a situation } \\
\text { misunderstood }\end{array}$} & $\begin{array}{l}\text { Focus shift to positive } \\
\text { agenda }\end{array}$ & $\begin{array}{l}\text { Offer on meanings that can shift the perceptions on the } \\
\text { organization. }\end{array}$ \\
\hline & & Fact generation & $\begin{array}{l}\text { Invention of events/episodes that can take the center } \\
\text { of attention, in order to target the visibility to positive } \\
\text { possible associations. }\end{array}$ \\
\hline & & $\begin{array}{l}\text { Paid strategies to shift } \\
\text { focus }\end{array}$ & $\begin{array}{l}\text { Usage of publicity inventory and the alternatives to make } \\
\text { different content visible in the formats and compositions } \\
\text { available in order to target the focus. }\end{array}$ \\
\hline & & $\begin{array}{l}\text { Infiltration of } \\
\text { organizational actors in } \\
\text { the discussions }\end{array}$ & $\begin{array}{l}\text { Introduction of "representatives" of the organization that } \\
\text { can be perceived as genuine by the public and, therefore, } \\
\text { influence/cross the course of discussions. }\end{array}$ \\
\hline & & Audience "Purchase" & $\begin{array}{l}\text { Hiring people to present the meanings desired } \\
\text { by organizations and oppose possible undesired } \\
\text { perspectives. }\end{array}$ \\
\hline & & $\begin{array}{l}\text { Incidence or hiring of } \\
\text { influencers }\end{array}$ & $\begin{array}{l}\text { Act of resorting to influencers (paid or persuasion method) } \\
\text { in order to assume and make attitudes visible that } \\
\text { endorse the organizational discourse and positioning. }\end{array}$ \\
\hline & & Problems in competition & $\begin{array}{l}\text { Shift of the focus of possible "negative" situations of } \\
\text { competitors, in a way that the visibility is (re)targeted to } \\
\text { an organization. }\end{array}$ \\
\hline & & $\begin{array}{l}\text { Search engine } \\
\text { optimization towards } \\
\text { visibility }\end{array}$ & $\begin{array}{l}\text { Usage of search engine optimization (SEO) techniques } \\
\text { in order to enhance versions of the organization about } \\
\text { certain agendas or subjects. }\end{array}$ \\
\hline \multirow{5}{*}{$\begin{array}{l}\text { Make it } \\
\text { invisible }\end{array}$} & \multirow{3}{*}{$\begin{array}{l}\text { Disregard } \\
\text { towards negative } \\
\text { associations or } \\
\text { mentions }\end{array}$} & $\begin{array}{l}\text { Scape or refusal to issue a } \\
\text { statement }\end{array}$ & $\begin{array}{l}\text { Silencing of the organization towards the highlighted } \\
\text { subject; act of fully leaving the scene in order to avoid } \\
\text { visibility, focus and attention. }\end{array}$ \\
\hline & & $\begin{array}{l}\text { Exclusion or hiding } \\
\text { comments or posts }\end{array}$ & $\begin{array}{l}\text { Usage of technical resources to not make the expression } \\
\text { of something that might "compromise" the organization } \\
\text { visible. }\end{array}$ \\
\hline & & $\begin{array}{l}\text { Take the conversation to a } \\
\text { private environment }\end{array}$ & $\begin{array}{l}\text { Targeting of exchanges to environments that are not } \\
\text { visible to other interlocutors. }\end{array}$ \\
\hline & \multirow{2}{*}{$\begin{array}{l}\text { Visibility } \\
\text { restriction } \\
\text { to desired } \\
\text { interlocutors }\end{array}$} & $\begin{array}{l}\text { Capture of contacts } \\
\text { through anonymous } \\
\text { techniques }\end{array}$ & $\begin{array}{l}\text { Access to interlocutors' data that appear to be relevant } \\
\text { to an organization in order to develop targeted visibility } \\
\text { initiatives. }\end{array}$ \\
\hline & & $\begin{array}{l}\text { Selection of audience } \\
\text { segments based on their } \\
\text { movement and behavior }\end{array}$ & $\begin{array}{l}\text { Construction of groups of interlocutors that appear to be } \\
\text { relevant to an organization because of objectives, needs, } \\
\text { or specific challenges. }\end{array}$ \\
\hline
\end{tabular}




\section{DISERTACIONES}

\section{AVANCES}

Los desafios del periodismo narrativo

ISSN: 1856-9536

Doi: https://doi.org/10.12804/revistas.urosario.edu.co/disertaciones/a.9058

Volumen 14, Número 1 / Enero-junio 2021

Versión PDF para imprimir desde

http://revistas.urosario.edu.co/index.php/disertaciones

\begin{tabular}{|c|c|c|c|}
\hline $\begin{array}{l}\text { Purposes/ } \\
\text { Intentionality }\end{array}$ & $\begin{array}{l}\text { Categories } \\
\text { (Strategies) }\end{array}$ & $\begin{array}{l}\text { Subcategories } \\
\text { (Emphasis) }\end{array}$ & Core Senses \\
\hline \multirow{6}{*}{$\begin{array}{l}\text { Make it } \\
\text { invisible }\end{array}$} & \multirow{4}{*}{$\begin{array}{l}\text { Reducing } \\
\text { the coverage } \\
\text { of content } \\
\text { distributed by } \\
\text { organizations }\end{array}$} & $\begin{array}{l}\text { Early appropriation of } \\
\text { formats and algorithm } \\
\text { changes }\end{array}$ & $\begin{array}{l}\text { Access to new rules, frameworks, and logics through } \\
\text { relationships with organizations responsible for social } \\
\text { media accounts. }\end{array}$ \\
\hline & & $\begin{array}{l}\text { Exploring formats of } \\
\text { content and time that do } \\
\text { not "perform" well }\end{array}$ & $\begin{array}{l}\text { Not exploring formats of content that are usually } \\
\text { successful (in reach and engagement) because of } \\
\text { algorithm logic. }\end{array}$ \\
\hline & & $\begin{array}{l}\text { No usage of "tagging"13 } \\
\text { techniques }\end{array}$ & $\begin{array}{l}\text { Premise to avoid tagging techniques in order to reduce } \\
\text { the possibility of a content to be viewed. }\end{array}$ \\
\hline & & $\begin{array}{l}\text { Restrain of the visibility to } \\
\text { non/few channels }\end{array}$ & $\begin{array}{l}\text { The non-usage of multimedia possibilities in order to } \\
\text { reduce coverage. }\end{array}$ \\
\hline & \multirow{2}{*}{$\begin{array}{l}\text { Establishment of } \\
\text { "comfort" policies }\end{array}$} & $\begin{array}{l}\text { Implementation of } \\
\text { guidelines towards the } \\
\text { presence of employees in } \\
\text { social media }\end{array}$ & $\begin{array}{l}\text { Establishment of rules to associate an employee to the } \\
\text { organization brand in social media. }\end{array}$ \\
\hline & & $\begin{array}{l}\text { Prior definition of } \\
\text { themes that must not be } \\
\text { addressed }\end{array}$ & $\begin{array}{l}\text { Agreement previously done about themes which the } \\
\text { organization will not be involved or will not speak about. }\end{array}$ \\
\hline
\end{tabular}

Source: By the authors.

As shown in Table 2, the perspective: "diagnose the visibility and invisibility" comprises a main strategy, which consists of monitoring situations that present problems to an organization or that have the potential to do so. In other words, it is about acting to identify and understand the scenarios, contexts, and meanings that compose such events. This concerns the strategic assumption about knowing a situation before decision-making. Thus, monitoring to build qualified diagnoses of risks and crises involving the organization is central to decision-making in the perspective to manage its visibility levels, that is, to define, among other things, what should be publicized, how, when, for how long, and in which media, as well as to establish, reinforce, or avoid associations with unwanted themes and facts. Therefore, this strategy is central to the movements that organizations carry out, whether in search of more visibility, or to move towards regions of greater opacity, reducing the levels of visibility, and, at the limit, entering spaces of invisibility in media (at least under certain aspects, facts, and specific themes).

From a strategic perspective, a more complex level of organization's visibility managing on social media updates the intention to "target visibility". In this sense and as we have pointed out, organizations use the knowledge obtained by monitoring and analyzing the different situations that involve them within the scope of social media (of course, this does not mean that it is only a matter of paying attention to what circulates in these

13 The tagging involves the choice of keywords that summarize the scope of a content. This possibility contributes to the better ranking of a webpage on the Google search engine, for instance. In some social media websites, such as Instagram and Twitter, the visibility of a publication is highly connected to the hashtags used. 


\section{DISERTACIONES}

\section{AVANCES}

Los desafios del periodismo narrativo

ISSN: 1856-9536

Doi: https://doi.org/10.12804/revistas.urosario.edu.co/disertaciones/a.9058

Volumen 14, Número 1 / Enero-junio 2021

Versión PDF para imprimir desde

http://revistas.urosario.edu.co/index.php/disertaciones

media, it should always be considered in the perspective of systemic interdependence), to define what should become relevant and visible from a sociotechnical perspective. Thus, they seek to take responsibility for defining what 'deserves light' and what should remain in the shadows, based on their desires and interests (we reaffirm that this is the intention of organizations, which does not mean that it is always done).

As highlighted in Table 2, two main strategies are used for this purpose. The first of them, "public expression of an institutional stance", comprises a set of deliberations and actions so that public approaches on a theme/ episode materialize from the organization's biases and conceptions, overlapping other perspectives. Here, the assumption is that when giving visibility to the version of the organization about a certain problem situation, it can focus on its resonance, tending to reduce the repercussion and even exercise itself to influence the versions and meanings that circulate in social media. It is worth noting that the non-participation of the organization in agendas that involve it or the absence of public manifestations tends to be perceived by the public as accommodation, disrespect, indicative of culpable responsibility, and as the realization of something illegal. In this way, silence (not saying anything) can increase clashes and repercussions on the problem situation.

The second one, the strategy of "shuffle of facts and emphasis to make a situation not understandable", meets the desire of organizations and agencies to confuse the public's understanding of a certain fact. Thus, they present and move other perspectives that have the potential to generate distraction, confusion, doubt, and deviations to muddle the flow of meanings in order to disturb the understanding of the public. It is necessary to note that this strategy has a wide potential for materializing unethical practices and diverging from issues of public interest.

In order to "make it invisible" on social media, there are four main strategies adopted by organizations and agencies. Under certain situations, after analyzing the context and the likely consequences of what is presented, one of the strategies is to "Disregard towards negative associations or mentions", that is, it is about non-manifestation (not expressing the institutional position) or acting by ignoring such problematic situations on social media, seeking to reduce their relevance. In other situations or in a complementary way with the strategy of "visibility restriction to desired interlocutors", they seek to limit visibility to a segment (or segments) of audiences, in order to make something invisible to other interlocutors. Other than these, the strategy of "reducing the coverage of content distributed by organizations" can be synthesized as an "apparent" visibility, produced by the use of socio-technical resources in the perspective of "making it invisible" -for example, by not using tagging techniques-. The fourth strategy, "establishment of 'comfort' policies", has as one of its assumptions the fact that to avoid (or reduce the chances of) public exposure of internal issues of the organization in an undesirable way, it is necessary to define the themes about which the organization does not manifest/involve, as well as establish rules and guide employees on how to position themselves on social media whenever they make any association with the organization.

We highlight the second purpose because it refers to strategies that involve the visibility of social media subjects. Given that this is not the focus of this study, this may call the attention in the first view. However, the research revealed that these paths are directly involved with invisibility, once there are strategies that target/aim the visibility, in a way that reduces the attention to an act perceived as "negative" or of little importance. In these cases, this is just the displacement of attention that ends up shadowing the thing that is desired to be hidden. 


\section{DISERTACIONES}

\section{AVANCES}

Besides, the informants repeatedly revealed the strategy in order to declare the desire to visibilize, but when there is a reflection upon it, we notice that the technical knowledge domain can lead to its use in a contrary sense -may it be the reduction/targeting of the visibility or the aim for invisibility-.

We believe that the studies conducted until now allow us to assure that there is a set of strategies that emphasize the reduction/targeting of visibility and invisibility. We rely on the analysis that emerged during the empiric data collection. In the next section, we present a diagram (Figure 1) with the strategies that seem to be the most frequently adopted by organizations in situations in which they aim to be invisible or in which they want to reduce or target visibility rates. The diagram contains the categories and subcategories presented before, organized in a system.

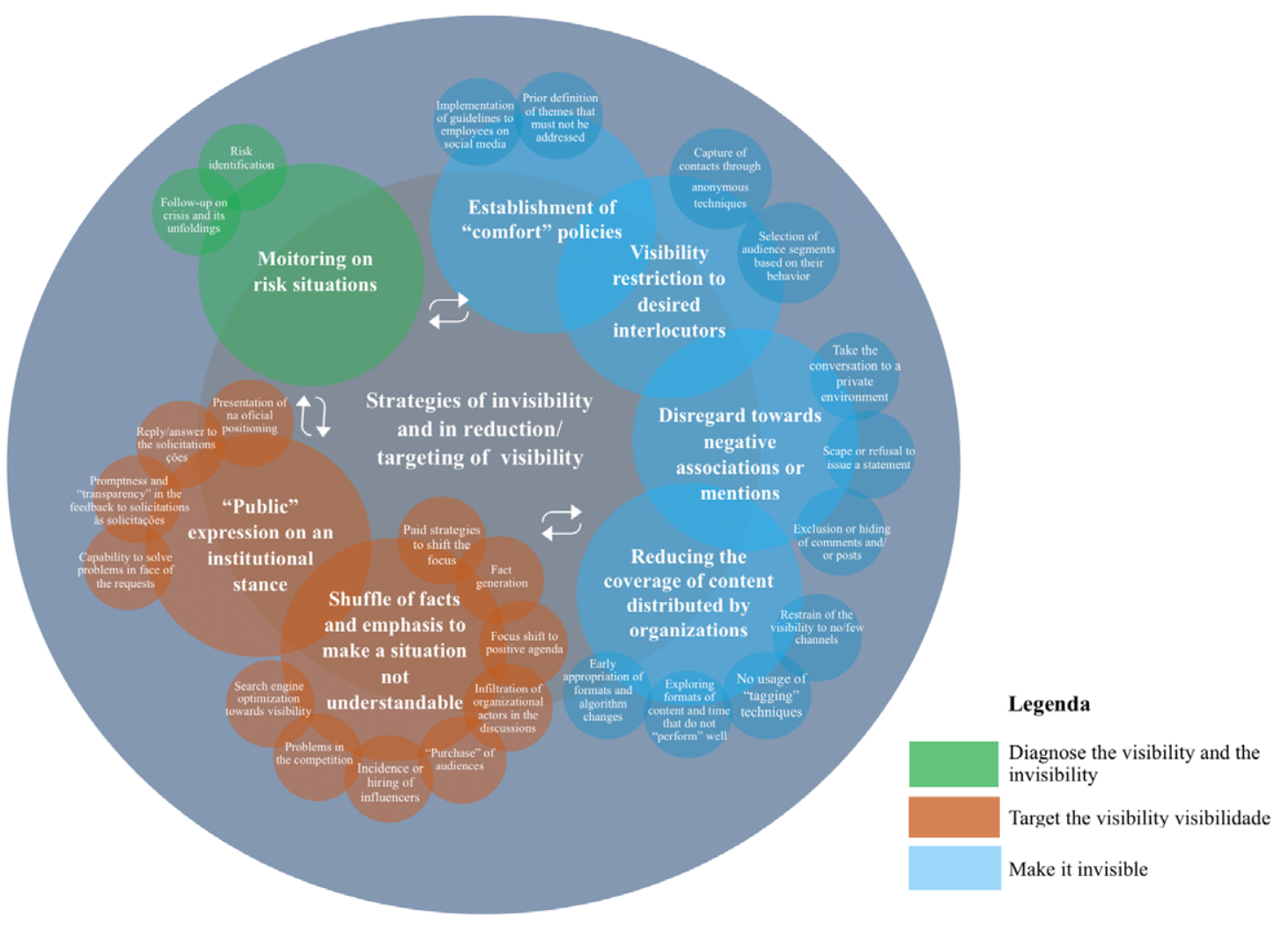

Fonte: The authors (2018)

Figure 1. Strategies of Invisibility and Reduction/Targeting of Visibility

These are the seven strategies that were identified in this research and the 25 subcategories that resulted from them, given the different sociotechnical emphasis. We highlight two main points presented in the diagram:

- The categories that work for a similar purpose are close, given that they respond to similar desires and intentionalities - we can see that they reveal interfaces, which we illustrated by the circles' intersection-. It is possible to identify three groups, each one in a different color. In order to ease the comprehension, 


\section{DISERTACIONES}

\section{AVANCES}

Los desafios del periodismo narrativo

ISSN: $1856-9536$

Doi: https://doi.org/10.12804/revistas.urosario.edu.co/disertaciones/a.9058

Volumen 14, Número 1 / Enero-junio 2021

Versión PDF para imprimir desde

http://revistas.urosario.edu.co/index.php/disertaciones

we presented a description underneath. The subcategories incorporated to each strategy are also directly connected, once it is possible that the comprehension of organizational practices reveals actions that may have complementary or hybrid characteristics, meeting or recurring to one or more sociotechnical emphasis. Still, it is important to pay attention to the insertion of different routes in the scheme of the map, given that, even though there are more evident intersections, all of the routes compose a unique map, with a broad set of possible dynamics.

- To complement this, the bidirectional arrows aim to reinforce the fact that an emphasis and a strategy are rarely adopted separately. On the contrary, we noticed that the agencies and the organizations organize these opportunities in the way that they see more favorable, given the situation and context. Therefore, there are many possibilities for arrangement. In the first moment, there is the prevalence of strategies that aim to the monitoring of risk situations. Analyzing some of the interviews, we noticed that there are many possibilities available in some situations, which vary from the degree of a perceived/diagnosed risk, the occupation of these invisibility paths, and how much the "conformity rules" are relevant to an organization.

It is important to highlight that the appropriation of the invisibility strategies and the reduction/targeting of the visibility can lead organizations to different levels of concealment of relevant matters to the public, which can comprehend subjects from moral issues to legal commitments. Observing and revealing such paths reshaped our concerns about this subject. After all, we did not understand the many alternatives and specificities of technical nature that make the invisibility strategies "more professional", including strategies of reduction or targeting the visibility within the social media context.

Now, with more clarity on the subject, our questions about these strategies are even more evident, especially in a way to discuss the conflict of interests with the notion of public interest. We also question how much the social dimension of the people is (not) respected, concerning the moral and ethical rules in society's (co)existence, and the high juxtaposition within the private interests scenario. It is a fact that the discovery of the level of knowledge of the sociotechnical artifacts in/of the agencies reveals how much of these processes are professionalized, also showing the alternatives to influence the perceptions and the public's opinion, or even to not allow an event to be visible. There is significant specialization, specifically towards social media websites, which also deserves to be highlighted.

In our empirical findings, therefore, logics, dynamics, and nuances were revealed and, whilst, they vest relevance in the subject. It is important to discuss the many ways that have the potential to retrieve the light (or reduce the clarity) to unfavorable focuses. These are "games" created by the organizations that entail decisions about which signs are going to be offered and which will be shuffled or eclipsed. Even though the process of creating meaning is not linear (Blumer, 1980; França, 2008), the signs start to compose the social relations net and to influence the perceived meanings and the concept-images that are (con)forming. The decision to disregard these aspects means giving up on a contemporary element that is relevant to organizational attempts to reinforce/sustain the positioning and the (attempts of) growth within levels of reliability.

Systematic disputes are behind these objectives and they overlap very little or nothing to desires and to the business strategies of the organizations. How much information that concern the public interest may have been hidden just this week? How many half-truths have we assumed as absolute truths lately? Which elements have brought light to the crises involving certain organizations that we became aware of this morning? Why did we not 


\section{DISERTACIONES}

\section{AVANCES}

Los desafios del periodismo narrativo

ISSN: 1856-9536

Doi: https://doi.org/10.12804/revistas.urosario.edu.co/disertaciones/a.9058

Volumen 14, Número 1 / Enero-junio 2021

Versión PDF para imprimir desde

http://revistas.urosario.edu.co/index.php/disertaciones

pay attention to a relevant issue that we read in a social media website, even though it is extremely worrying? These are questions that gain strength given the results of this research, and the answers involve the invisibility and reduction/targeting of visibility strategies.

It is clear that being under the spotlight may be negative for organizations in some contexts. We have seen how many strategies exist and the technical refinement adopted in these situations, facts that are not very often discussed. The sociotechnical resources enable these initiatives and they are boosted by the lack of procedures to stop them, or even consequence policies that make the companies reflect about the risks to society. These discussions become even more obscure because we are talking about something that is not in an apparent level. How do we shine light in something that is not seen? How do we reveal the other side of the coin, given that the most prominent discussions are about the visibility performances? Given these issues, Thompson's (2008) proposition suits very well: the "act of seeing is always shaped by a more broad aspect" that does beyond what is said and materialized.

Using a drama metaphor, just like it is shown by Goffman (2009), the moves that the strategies represent are acts translated by very well-rehearsed performances, through sequentially conceived scenes. They bring certain representations to the center stage, to visibility zones, and these representations aim to hide what happens in the backstage, in the green room. We can see the desire to conceal and to retrieve visibility of production elements, sometimes with the intent of masking the real intentions from the involved agents.

\section{Discussion and Research Considerations}

Even though most of the interviews cover experiences from social media like Facebook, Twitter, Instagram and LinkedIn, the strategies are not limited to them. Of course, there are different nuances of sociotechnical order in each one of these medias, but none of the paths refer to a specific one. This is an important point. After all, we can see the appearance of a new medium and a decline of others in an everyday basis. Concerning this trait, our map gets a longer "lifetime", and tends to last longer, because even if a media ceases to exist, the strategies linger. The environments change and, perhaps, other possibilities directly correlate to functional resources and technical of new social media are added, but the pathway and the results of our research are not invalidated. Thus, the map can add on new strategies, be revised from time to time, fit the sociotechnical characteristics of any new subcategory, but we will not lose the timeline of this expertise and the progress on the comprehension of these ways.

Under these considerations, we reaffirm that the option to build a strategy map answers to the simple goal of making our didactic learning more palatable, especially, given the high number of emphasis. They are "orchestrated" in a combined way, in chains/sequences or simultaneously from challenges, "abilities", levels of responsibility, and ethical commitments (or the lack of them) from the professionals that suggest and conduct them. The arrangements are diverse and can involve strategies constructed from many categories, which is a situation that new studies can portray.

There are two points that emerge from these reflections and need to be clear because they appear to be the most important contributions by this study. First, we need to take up and contribute to visibility, towards the publicization of the discussions about the alternatives of invisibility and reduction/targeting of visibility. We are talking about a "market practice" that rarely stressed within academic spaces. The results revealed several 


\section{DISERTACIONES}

AVANCES

Los desafíos del periodismo narrativo

ISSN: 1856-9536

Doi: https://doi.org/10.12804/revistas.urosario.edu.co/disertaciones/a.9058

Volumen 14, Número 1 / Enero-junio 2021

Versión PDF para imprimir desde

http://revistas.urosario.edu.co/index.php/disertaciones

possible alternatives. Even though we cannot diagnose exactly the incidence of this process in the context of organizational practices, it is a fact that they exist. It is equally noteworthy the high professionalization of these processes and the appropriation of sociotechnical resources, which are not very transparent to society.

Our perceptions about the empirical data indicate that the discussions about conformity, ethics and morals are not the priority when the organizations recur to these resources. This is a very worrying attitude, which makes us think about the way professionals can be able to assume social commitment to society, inherent to the mission of a professional in communication (at least in an idealistic perspective), beyond the scope of technical practices that are able to potentialize the performances and results expected by organizations. Another important aspect concerns the qualifications and technical apprenticeship and the fact that they are related to the empirical experience that these professionals acquire and to short courses offered by companies that center their concerns towards top performances. The contents of these courses do not offer more consistent discussions within the perspective we commented. Maybe the communication field lacks the conceptual and real notion of the impacts that these strategies can cause. In other cases, there may be more clarity, but the market interests and the concept images end up trumping conformity foundation pillars.

Thus, we get to the second point: the notion of public interest is being ignored -at least partly and in some situations-. Again, we cannot assure how frequent the invisibility and the reduction/targeting of visibility strategies are in the historical moment we are. However, it is evident that certain practices oppose to the transparency and the right of the public and society to information. The organizations sometimes present partial versions of facts and present them as "the truth". The main concern is to avoid/reduce damage to the concept images of the organizations and earn good results. These initiatives' impacts may still take a long time to gain visibility, which, once again, is worrisome. To expose these practices and contribute to the debate on this may be a first move to change this picture.

\section{References}

1. Baldissera, R. (2008). Significação e comunicação na construção da imagem-conceito. Revista Fronteiras. Estudos Midiáticos, 10(3), 193-200. http://revistas.unisinos.br/index.php/fronteiras/article/view/5397

2. Baldissera, R. (2009). Comunicação organizacional na perspectiva da complexidade. Organicom, 6(10-11), 115-120. https://doi.org/10.11606/issn.2238-2593.organicom.2009.139013

3. Bardin, L. (2011). Análise de conteúdo. Edições 70.

4. Blumer, H. (1980). A natureza do interacionismo simbólico. In C. D. Mortensen (Ed.), Teoria da comunicação: textos básicos (pp. 119-137). Mosaico.

5. França, V. V. (2008). Interações comunicativas: a matriz conceitual de gH Mead. In A. Primo et al. (Org.), Comunicação e interações (pp. 71-91). Sulina.

6. Goffman, E. (2009). A representação do eu na vida cotidiana. Ed. Vozes.

7. Henriques, M. S., \& Silva, D. R. (2014). Vulnerabilidade dos públicos frente a práticas abusivas de comunicação empregadas por organizações: limitações para o monitoramento civil. Comunicação e Sociedade, 26, 162-176. 
8. Hoggan, J. (2006). Astroturf: the only grass that withstands toxic friends of science. http://www.desmogblog. com/astroturf-the-only-grass-that-withstands-toxicfriends-of-science

9. Lasta, E. (2017). Estratégias sociotécnicas de visibilidade e legitimidade na comunicação organizacional em rede. In Anais do $40^{\circ}$ Congresso Brasileiro de Ciências da Comunicação. https://portalintercom.org.br/ anais/nacional2017/resumos/R12-2846-1.pdf

10. Rossetti, J. P., \& Andrade, A. (2014). Governança corporativa: fundamentos, desenvolvimento e tendências. Atlas.

11. Silva, D. R. (2013). O astroturfing como um processo comunicativo: enquadramentos na manifestação encenada de um público. In Anais do $5^{\circ}$ Congresso da Assiciação Brasileira de Pesquisadores em Comunicação Política. http://www.compolitica.org/home/wp-content/uploads/2013/05/GT06-Cultura-politica-comportamento-e-opiniao-publica-DanielReisDaSilva.pdf

12. Thompson, J. B. (2008). A nova visibilidade. Matrizes, 1(2), 15-38.

13. Wood Jr., T. (2001). Organizações espetaculares. FGV. 